\title{
Potential of Spring Barley, Oat and Triticale Intercrops with Field Peas for Forage Production, Nutrition Quality and Beef Cattle Diet
}

\author{
Kabal S. Gill ${ }^{1} \&$ Akim T. Omokanye ${ }^{2}$ \\ ${ }^{1}$ SARDA Ag Research, Falher, Alberta, Canada \\ ${ }^{2}$ Peace Country Beef \& Forage Association, Animal Science Building, Grande Prairie Regional College, Fairview, \\ Alberta, Canada \\ Correspondence: Kabal S. Gill, SARDA Ag Research, 701 Main Street, Box 90, Falher, Alberta T0H 1M0, \\ Canada. Tel: 1-780-837-2900. E-mail: consultant@sarda.ca
}

Received: December 18, 2017

Accepted: January 24, 2018

Online Published: March 15, 2018

doi:10.5539/jas.v10n4p1

URL: https://doi.org/10.5539/jas.v10n4p1

\begin{abstract}
Spring barley (Hordeum vulgare L.), oat (Avena sativa L.) and triticale (x Triticosecale Wittmack) monocrops and their intercrops with two forage varieties (40-10 and Tucker) and one seed variety (Cooper) peas (Pisum sativum L.) were evaluated for forage production, nutrition quality and suitability in the beef cattle diet. Pea + cereal intercrops were compared to respective cereal monocrops in 2009, 2010 and 2011. Plant height of cereals tended to be reduced in intercrops compared to respective monocrops. Taller 40-10 forage type pea tended to cause lodging in 2009 and 2011, not observed with other pea varieties. Fresh forage of pea + cereal intercrops had higher moisture than respective cereal monocrops. Fourteen of the 18 intercrops had less dry matter yield (DMY) than respective cereal monocrops. Shorter Tucker pea had less negative impact on DMY than taller 40-10 pea. Treatments with barley had lower DMY than respective oat and triticale systems. Intercrops improved forage crude protein $(\mathrm{CP})$ content over the respective monocrops, which was enough to overcome the DMY penalty and produce more $\mathrm{CP}$ yield than their monocrops. The forage $\mathrm{Ca}$ and $\mathrm{Mg}$ contents were improved by intercrops over their monocrops, and they were greater with 40-10 pea than other pea varieties and with barley than oat or triticale. The forage P content also tended to be higher in intercrops than corresponding monocrops, without a consistent effect of cereal type or pea variety. The forage $\mathrm{K}$ and $\mathrm{S}$ contents were not consistently influenced by the cereal types, pea varieties or intercrops. Forage Na content was greater from oat than respective barley and triticale treatments. The monocrops and intercrops had similar forage $\mathrm{Cu}$ content, and treatments with barley had more $\mathrm{Cu}$ than with oat or triticale. Forage $\mathrm{Zn}$ content tended to be intercrops $>$ monocrops; and barley > triticale > oat. Treatments had no influence on the forage $\mathrm{Fe}$ and $\mathrm{Mn}$ contents. Levels of acid (ADF) and neutral (NDF) detergent fibres in the forage were similar for the corresponding intercrops and monocrops, and greater for oat than barley or triticale treatments. Some of the intercrops improved total digestible nutrients (TDN) content in forage over their monocrops. Monocrop of oat had less TDN than barley or triticale. Drought reduced the $\mathrm{ADF}, \mathrm{NDF}$ and TDN contents. The forage $\mathrm{NE}_{\mathrm{L}}, \mathrm{NE}_{\mathrm{M}}$ and $\mathrm{NE}_{\mathrm{G}}$ as well as RFV and NFC showed similar trend as the TDN. Overall, the tested pea + cereal intercrops did not increase DMY over the respective monocrops, but they indicated several nutritional quality benefits. These improvements present opportunities to substitute some grain or supplements in the beef cattle diet with better quality forage by intercrops.
\end{abstract}

Keywords: barley, forage yield, pea + cereal intercrop, nutritional value, oat, pea, subarctic climate, triticale

\section{Introduction}

Intercropping refers to the simultaneous growing of at least two crop species in close proximity at (about) the same time, leading to enhanced interspecific interactions and crop diversity ( $\mathrm{Li}$ et al., 2014). The recent review by Xue et al. (2016) on crop acquisition of phosphorus, iron and zinc from soil indicated that intercropping of cereal + legume crops is the most commonly used system reported in the literature.

Intercropping systems involving cereals with legumes, have been observed to provide several major advantages such as higher total yield and better land use efficiency (Dhimal et al., 2007; Brooker et al., 2015), yield stability (Lithourgidis et al., 2006, 2007), better utilization of light, water, and nutrients (Javanmard et al., 2009; Brooker et al., 2015), improved soil conservation (Anil et al., 1998; Brooker et al., 2015), and maintenance of soil 
fertility. Inclusion of grain legumes in intercrops has increased forage protein yields, and improved forage nutritive value (Anil et al., 1998; Carr et al., 1998; Strydhorst et al., 2008).

In temperate areas of the world, intercropping has been more widely adopted for forage production rather than for grain production (Anil et al., 1998). The two common types of intercropping in Alberta, Canada are peas plus oats, barley or triticale, and combinations of spring cereals with winter wheat, winter triticale or fall rye (AARD, 2004). Peas are usually included in mixes to improve quality of the feed. In the Peace Country (PC) region of Alberta, barley and oat are the major cereal crops grown for forages, although some triticale is also harvested as forages. Triticale is a dual-purpose cereal crop and it therefore has the potential to provide economic benefits for both grain and forage based production systems (Igne et al., 2007).

Sustainable management involves matching the nutritional quality of forage types with the nutrient needs of different beef cow categories. To improve annual cereal and legume forages utilization as hay, green feed or silage and to develop supplementation programs for forage-based nutrition, it is important to know how the nutritional values of different forages match up with beef cow needs. Studies to identify promising barley (Gill et al., 2013a) oat (Gill et al., 2013b), and triticale (Gill \& Omokanye, 2016) varieties for beef cattle production systems have been conducted in the PC region of Alberta. The objectives of this study were to compare the intercrops of spring oat, barley and triticale with pea varieties to respective cereal monocrops grown in the north western (PC) Alberta, Canada; in terms of their forage yield, and feed quality. The implications of the findings are discussed for their forage use in the beef cow production system.

\section{Materials and Methods}

\subsection{Study Sites}

The studies were carried out from 2009 to 2011 on farmer's fields in High Prairie (2009 \& 2011; 55 $26^{\circ} \mathrm{N}$, $116^{\circ} 29^{\prime} \mathrm{E}$; $732 \mathrm{~m}$ above sea level) and Valleyview $\left(2010 ; 55^{\circ} 04^{\prime} \mathrm{N}, 117^{\circ} 17^{\prime} \mathrm{W} ; 762 \mathrm{~m}\right.$ above sea level) in northwest (PC) Alberta, Canada. The climate at the sites is subarctic, which is generally characterized by long, usually very cold winters (December-March), and short, cool to mild summers (June-August). Gill et al. (2013a, b) have earlier provided weather information for both sites during the same period (Table 1).

Table 1. Spring soil moisture (SSM) and rainfall in the crop growing months for different years, and their long-term averages (LTA)

\begin{tabular}{llllll}
\hline \multirow{2}{*}{ Year and site } & \multicolumn{5}{c}{ SSM and monthly rainfall, mm } \\
\cline { 2 - 6 } & SSM & May & June & July & Total \\
\hline 2009 High Prairie & 100 & 33 & 9 & 92 & 234 \\
2010 Valleyview & 37 & 36 & 17 & 42 & 132 \\
2011 High Prairie & 35 & 38 & 166 & 83 & 322 \\
LTA & 91 & 42 & 84 & 83 & 303 \\
\hline
\end{tabular}

According to the Soil Classification working Group (1998), High Prairie soil is an Ortho Humic Gleysol, with dark colour, and sandy to clay loam texture, while the soil at Valleyview is a Grey Luvisol with loam to clay loam texture. The surface soil (top 0-15 cm) was tested using standard methods as per the Soil \& Plant Analysis Council (1999), from the A\&L Laboratory, London, Ontario, Canada. More details are described in Gill et al. (2013a, 2013b). Soil samples had $74 \mathrm{~g} \mathrm{~kg}^{-1}$ organic matter, $6.4 \mathrm{pH}$ (water), $22.4 \mathrm{cmol}(+) \mathrm{kg}^{-1}$ CEC, $12 \mathrm{mg} \mathrm{kg}^{-1}$ Bray 1-P, $165 \mathrm{mg} \mathrm{kg}^{-1}$ extractable K, $2990 \mathrm{mg} \mathrm{kg}^{-1} \mathrm{Ca}, 675 \mathrm{mg} \mathrm{kg}^{-1} \mathrm{Mg}$, and $17 \mathrm{mg} \mathrm{kg}^{-1} \mathrm{NO}_{3}-\mathrm{N}$ at High Prairie; and had $63 \mathrm{~g} \mathrm{~kg}^{-1}$ organic matter, $5.5 \mathrm{pH}$ (water), $17.2 \mathrm{cmol}(+) \mathrm{kg}^{-1} \mathrm{CEC}, 21 \mathrm{mg} \mathrm{kg}^{-1}$ Bray 1-P, $185 \mathrm{mg} \mathrm{kg}^{-1}$ extractable $\mathrm{K}, 1350 \mathrm{mg} \mathrm{kg}^{-1} \mathrm{Ca}, 295 \mathrm{mg} \mathrm{kg}^{-1} \mathrm{Mg}$, and $43 \mathrm{mg} \mathrm{kg}^{-1} \mathrm{NO}_{3}-\mathrm{N}$ at Valleyview site.

\subsection{Experimental Design, Treatments \& Agronomic Procedures}

A randomized complete block design with four replications was used in each site-year. There were nine (9) treatments consisting of three (3) cereal monocrops (barley, oat and triticale) and six (6) pea-cereal intercrops in each site-year (Table 2). Pea monocrop treatments were not included because the study objective was to improve forage quality by intercropping pea with cereals. The following varieties were used for cereals: Murphy for oat, Vivar for barley and Pronghorn for triticale. For peas, the varieties used were 40-10 and Tucker in 2009 and 2011; and 40-10 and Cooper in 2010 (because Tucker seed was not available in 2010). 
Vivar barley is a 6-row feed type. Murphy oat is a forage type. Pronghorn triticale is a spring variety, drought tolerant cereal crop and an excellent alternative to feed barley and oats. Cooper pea is a yellow seed pea variety. Tucker and 40-10 peas are forage type varieties.

Small plots measured 10 or $8.5 \mathrm{~m}$ in length and $1.4 \mathrm{~m}$ width (had 6 crop rows at $23 \mathrm{~cm}$ spacing). Seeding rate was at the recommended seed density of 250 seeds $\mathrm{m}^{-2}$ (using 1000 -seed weight and germination) for monocrop cereals. For intercropped treatments, seeding rate was 58 seeds $\mathrm{m}^{-2}$ of field peas $(75 \%$ of recommended mono-crop seeding rate) plus 125 seeds $\mathrm{m}^{-2}$ (50\% of cereal monocrops). The peas were inoculated before seeding.

Canola (Brassica napus L.) was the crop before each study site-year. The test areas were cultivated in the previous fall and a pre-seed weed control in spring was carried out with glyphosate. A Fabro plot drill was used to seed and apply fertilizers, on May 23 in 2009, May 16 in 2010 and May 20 in 2011. Combinations of seed row placed (11-52-0) and side banded (46-0-0, 0-0-60, 20-0-0-24) fertilizers were used to apply soil test based recommended nutrients. Rates of nutrients applied in 2009, 2010 and 2011, respectively, were 74, 5 and $56 \mathrm{~kg} \mathrm{~N}$ $\mathrm{ha}^{-1}, 50,20$ and $34 \mathrm{~kg} \mathrm{Pha}^{-1}, 74,17$ and $22 \mathrm{~kg} \mathrm{~K} \mathrm{ha}^{-1}$, and 0,0 and $34 \mathrm{~kg} \mathrm{~S} \mathrm{ha}^{-1}$. In 2010, additional $30 \mathrm{~kg} \mathrm{~N} \mathrm{ha}^{-1}$ was applied to the cereal monocrops only. No in-crop spraying was done in any of the three years. Occasional hand weeding was done to remove volunteer canola plants.

\subsection{Plant Height, Lodging and Dry Matter Yield}

Before harvesting, lodging was assessed visually and plant height was measured on 3 randomly selected plants from each plot. The peas and cereals plant heights in the intercrops were measured separately.

The above ground parts of plants were harvested from $6 \mathrm{~m}$ long 4 inner rows and weighed fresh. Harvesting was done at soft dough stage of barley for monocrop and pea + barley intercrops; at milk stage of oat for monocrop and pea-oat intercrops; and at late milk stage of triticale for monocrop and pea + triticale intercrops. About 0.5 $\mathrm{kg}$ of freshly harvested materials (sub-sample) was oven-dried at $50^{\circ} \mathrm{C}$ to constant weight for forage dry matter yield (DMY) determination as well as nutritive value analyses.

\subsection{Forage Nutritive Value Analysis and Calculations}

The forage nutritive value was determined from composite samples of all the 4 replications in 2009. In 2010 and 2011, two samples per treatment were used for nutrition measurements. Sample 1 was composite of forage materials from replications $1 \& 2$, while sample 2 was composite of materials from replications $3 \& 4$.

The samples were analyzed for various nutritive value measurements in a commercial laboratory (A\&L Laboratory, London, Ontario, Canada) using standard procedures for wet chemistry, as earlier provided by Gill et al. (2013a, 2013b). Crude protein yield (CPY) and total digestible nutrients yield (TDNY) were determined by multiplying forage DMY $\left(\mathrm{Mg} \mathrm{ha}^{-1}\right)$ with $\mathrm{CP}$ and TDN contents, respectively.

\subsection{Statistical Analysis}

The data were subjected to analysis of variance (ANOVA) for each year, because Tucker pea seed was not available in 2010 and it was replaced with cooper peas. Inability to use same pea varieties in all years precluded 3 year combined statistical analyses and comparison between different years. Where ANOVA indicated significant treatment effects, the means were separated by the protected least significant difference (LSD) at the 0.05 probability level. The coefficient of variation (\%) for each parameter is also presented to indicate variability.

\section{Results and Discussion}

\subsection{Plant height, Lodging, and Forage Moisture}

For cereal crops, plant height was in the order of Murphy oat $>$ Pronghorn triticale $>$ Vivar barley (Table 2). Plant height for peas showed a sequence of 40-10 > Tucker $>$ Cooper. The genetic make-up of the tested crop species and varieties were responsible for the higher plant height obtained for Murphy oat and 40-10 pea, which were developed specifically for forage production. Both Tucker and 40-10 peas are forage type varieties, hence are taller than a grain type Cooper pea. 
Table 2. Cereal and pea plant heights in the cereal monocrops and pea + cereal intercrops

\begin{tabular}{|c|c|c|c|c|c|c|}
\hline \multirow{2}{*}{ Treatment } & \multicolumn{3}{|c|}{ Cereals plant height $(\mathrm{cm})$} & \multicolumn{3}{|c|}{ Pea plant height $(\mathrm{cm})$} \\
\hline & 2009 & 2010 & 2011 & 2009 & 2010 & 2011 \\
\hline Vivar barley & 82 & 48 & 97 & $\mathrm{n} / \mathrm{a}$ & $\mathrm{n} / \mathrm{a}$ & $\mathrm{n} / \mathrm{a}$ \\
\hline Murphy oat & 133 & 93 & 157 & $\mathrm{n} / \mathrm{a}$ & $\mathrm{n} / \mathrm{a}$ & $\mathrm{n} / \mathrm{a}$ \\
\hline Pronghorn triticale & 113 & 89 & 136 & $\mathrm{n} / \mathrm{a}$ & $\mathrm{n} / \mathrm{a}$ & $\mathrm{n} / \mathrm{a}$ \\
\hline Cooper pea + Vivar barley & $\mathrm{n} / \mathrm{a}$ & 47 & $\mathrm{n} / \mathrm{a}$ & $\mathrm{n} / \mathrm{a}$ & 28 & $\mathrm{n} / \mathrm{a}$ \\
\hline Cooper pea + Murphy oat & $\mathrm{n} / \mathrm{a}$ & 92 & $\mathrm{n} / \mathrm{a}$ & $\mathrm{n} / \mathrm{a}$ & 27 & $\mathrm{n} / \mathrm{a}$ \\
\hline Cooper pea + Pronghorn triticale & $\mathrm{n} / \mathrm{a}$ & 84 & $\mathrm{n} / \mathrm{a}$ & $\mathrm{n} / \mathrm{a}$ & 27 & $\mathrm{n} / \mathrm{a}$ \\
\hline Tucker pea + Vivar barley & 80 & $\mathrm{n} / \mathrm{a}$ & 97 & 90 & $\mathrm{n} / \mathrm{a}$ & 124 \\
\hline Tucker pea + Murphy oat & 126 & $\mathrm{n} / \mathrm{a}$ & 155 & 95 & $\mathrm{n} / \mathrm{a}$ & 133 \\
\hline Tucker pea + Pronghorn triticale & 111 & $\mathrm{n} / \mathrm{a}$ & 130 & 97 & $\mathrm{n} / \mathrm{a}$ & 126 \\
\hline 40-10 pea + Vivar barley & 84 & 48 & 94 & 134 & 53 & 163 \\
\hline 40-10 peas + Murphy oat & 121 & 92 & 139 & 140 & 55 & 164 \\
\hline 40-10 pea + Pronghorn triticale & 106 & 87 & 122 & 140 & 58 & 164 \\
\hline$L S D_{(0.05)}$ & 5.8 & 3.7 & 4.6 & 6.4 & 6.2 & 21.7 \\
\hline Significance & $* * *$ & $* *$ & $* *$ & $* * *$ & $* *$ & $* *$ \\
\hline$C V, \%$ & 3.7 & 3.3 & 2.5 & 3.7 & 10.0 & 9.9 \\
\hline
\end{tabular}

Note. $^{* * *}$ and ${ }^{* *}$ indicates the treatments effect being significant at 0.001 and 0.01 probability, respectively. $\mathrm{n} / \mathrm{a}$ refers to not applicable, because the pea variety was not tested.

The 3 cereals tended to be shorter when they were grown in intercrops with peas than as monocrops, with a few exceptions, and the height reduction was significant in several treatments (Table 2). For example, the reduction in plant height was significant for the Murphy oat in intercrops with both pea varieties in 2009 and with 40-10 in 2011; and for the Pronghorn triticale in intercrops with 40-10 in 2009, with Cooper in 2010, and with both pea varieties in 2011. Shorter cereals in intercrops could be attributed to competition by the peas. Corre-Hellou et al. (2006) stated that the leaf area of the peas (dominant crop species) in the intercrops might have increased when more $\mathrm{N}$ was available, thereby enhancing its ability to intercept the solar radiation and, therefore, being able to shade the companion cereal crop species. Amongst the intercrop treatments, neither the cereals plant height was influenced by the pea variety and nor the pea height was influenced by the cereal type consistently, even though both the cereals and pea varieties had considerable differences in their heights.

Compared to the 2009 and 2011, the crops were shorter in 2010 (Table 2), due to much lower spring soil moisture and rain in 2010 (Table 1). The total rainfall received from May to July in 2010 was 44 and 59\% less than in 2009 and 2011, respectively.

There was no lodging for any of the treatments in 2010. In 2009 and 2011, the intercrop treatments with 40-10 showed mild lodging while no lodging was observed in other treatments (data not shown). Taller 40-10 pea plants were observed to lean on cereals that caused lodging.

Fresh forage of all the pea + cereal intercrops had higher moisture level than the corresponding monocrops of the cereals, except for similar moisture level in the 40-10 pea + Vivar barley intercrop and monocrop of Vivar barley, and the increase was significant by 11 of the 18 intercrops grown in 3 years (Table 3). Apparently, pea portion of the intercrops had higher moisture levels than the cereal portion. Higher moisture level of intercrops than monocrops may need adjusting the harvest time to obtain desired wetness for appropriate use of forage. 
Table 3. Moisture content (wet basis) and dry matter yield of forage from the cereal monocrops and mixture of pea + cereal intercrops

\begin{tabular}{|c|c|c|c|c|c|c|}
\hline \multirow{2}{*}{ Treatment } & \multicolumn{3}{|c|}{ Moisture content $(\%)$} & \multicolumn{3}{|c|}{ Dry matter yield $\left(\mathrm{Mg} \mathrm{ha}^{-1}\right)$} \\
\hline & 2009 & 2010 & 2011 & 2009 & 2010 & 2011 \\
\hline Vivar barley & 72.6 & 59.6 & 68.5 & 2.87 & 1.74 & 4.91 \\
\hline Murphy oat & 74.0 & 57.1 & 77.1 & 3.97 & 1.99 & 3.98 \\
\hline Pronghorn triticale & 65.0 & 54.4 & 69.6 & 3.98 & 2.16 & 4.26 \\
\hline Cooper pea + Vivar barley & $\mathrm{n} / \mathrm{a}$ & 64.4 & $\mathrm{n} / \mathrm{a}$ & $\mathrm{n} / \mathrm{a}$ & 1.59 & $\mathrm{n} / \mathrm{a}$ \\
\hline Cooper pea + Murphy oat & $\mathrm{n} / \mathrm{a}$ & 61.4 & $\mathrm{n} / \mathrm{a}$ & $\mathrm{n} / \mathrm{a}$ & 1.78 & $\mathrm{n} / \mathrm{a}$ \\
\hline Cooper pea + Pronghorn triticale & $\mathrm{n} / \mathrm{a}$ & 58.2 & $\mathrm{n} / \mathrm{a}$ & $\mathrm{n} / \mathrm{a}$ & 1.73 & $\mathrm{n} / \mathrm{a}$ \\
\hline Tucker pea + Vivar barley & 74.9 & $\mathrm{n} / \mathrm{a}$ & 74.2 & 2.32 & $\mathrm{n} / \mathrm{a}$ & 3.90 \\
\hline Tucker pea + Murphy oat & 75.4 & $\mathrm{n} / \mathrm{a}$ & 80.4 & 4.54 & $\mathrm{n} / \mathrm{a}$ & 3.35 \\
\hline Tucker pea + Pronghorn triticale & 72.3 & $\mathrm{n} / \mathrm{a}$ & 74.8 & 4.26 & $\mathrm{n} / \mathrm{a}$ & 3.49 \\
\hline 40-10 pea + Vivar barley & 72.6 & 63.9 & 80.1 & 2.69 & 1.60 & 3.27 \\
\hline $40-10$ peas + Murphy oat & 76.7 & 59.8 & 80.1 & 4.06 & 2.00 & 3.00 \\
\hline 40-10 pea + Pronghorn triticale & 74.6 & 58.7 & 77.8 & 4.16 & 2.12 & 3.35 \\
\hline$L S D_{(0.05)}$ & 3.01 & 3.80 & 3.54 & 0.464 & 0.266 & 0.596 \\
\hline Significance & $* * *$ & $* *$ & $* *$ & $* * *$ & $* *$ & $* *$ \\
\hline$C V, \%$ & 2.8 & 4.4 & 3.2 & 8.7 & 9.8 & 11.0 \\
\hline
\end{tabular}

Note. ${ }^{* *}$ and ${ }^{* *}$ indicates the treatments effect being significant at 0.001 and 0.01 probability, respectively. $\mathrm{n} / \mathrm{a}$ refers to not applicable, because the pea variety was not tested.

\subsection{Forage Dry Matter Yield (DMY)}

Fourteen (14) of the 18 tested pea + cereal intercrops produced less forage DMY compared to the corresponding monocrops of cereals, and the decline was significant in 8 intercrops (Table 3). In 4 intercrops that produced higher DMY compared to the pea + cereal intercrops, only the Tucker pea + Murphy oat in 2009 provided significant benefit. Thus there appears to be a forage DMY penalty from intercrops compared to the corresponding monocrop cereals in most treatments.

The 2010 results indicated a tendency for higher DMY from the 40-10 pea + cereals compared to the Cooper + cereals intercrops, with significant differences between their intercrops with triticale. Considering the data from 2009 and 2011 years, when both the Tucker and 40-10 pea varieties were tested, the DMY was somewhat greater from the Tucker pea + cereal than from the 40-10 pea + cereal intercrops, except in 2009 when the DMY was slightly more from intercrop of Vivar barley with 40-10 than with Tucker pea. It may be mentioned that the differences were usually small and not significant. The average DMY across all the 3 cereals was 3.64 and 3.43 $\mathrm{Mg} \mathrm{ha}^{-1}$ for the intercrops of Tucker pea + cereals and 40-10 pea + cereals, respectively, in 2009 and 2011. Tucker peas could therefore be used as good companion crop with cereals in pea + cereal mixtures for silage or green feed production in the study area, in consideration of lodging and DMY.

In most treatments, Vivar barley monocrop and its associated intercrops appeared to have lower forage DMY than the other cereal monocrops and intercrops. Based on the data from 2009 and 2011 years, when both the Tucker and 40-10 pea varieties were tested with the 3 cereals, the DMY from the Vivar barley monocrop was 0.09 and $0.23 \mathrm{Mg} \mathrm{ha}^{-1}$ lesser than from the Murphy oat and Pronghorn triticale monocrops, respectively. Corresponding differences were 0.83 and $0.77 \mathrm{Mg} \mathrm{ha}^{-1}$ for their intercrops with Tucker pea, and were 0.55 and $0.80 \mathrm{Mg} \mathrm{ha}^{-1}$ for their intercrops with the 40-10 pea. The differences in DMY from the tested Murphy oat and Pronghorn triticale monocrops and their intercrops were relatively small and not consistent.

Overall, the results indicated that the tested intercrops did not provide a DMY benefit, and tested monocrops and intercrops of Vivar barley produced less DMY than the corresponding Murphy oat and Pronghorn triticale systems. Carr et al. (1998) observed no significant DMY benefit form barley + pea intercrops, attributed to domination of the intercrops by barley. Aasen at al. (2004) and Strydhorst et al. (2008) also found cereal + pea systems did not out yield monocrops. On the other hand, yield increase of forage legume-cereal intercrops relative to cereal monocrops have been reported by Carr et al. (2004).

\subsection{Forage Crude Protein (CP), CP Yield (CPY) and CP Fractions}

The forage $\mathrm{CP}$ content in monocrops generally showed a sequence of barley $>$ triticale $>$ oat (Table 4). Results of higher CP obtained for Vivar barley and Pronghorn triticale monocrops than Murphy oat monocrop in the present 
study are supported by the earlier findings of Gill et al. (2013a, 2013b), and Gill and Omokanye (2016) on the evaluation of barley, oat and triticale varieties for silage production in the same environment.

Table 4. Crude protein (CP) concentration and yield for forage from the cereal monocrops and mixture of pea + cereal intercrops

\begin{tabular}{|c|c|c|c|c|c|c|}
\hline \multirow{2}{*}{ Treatment } & \multicolumn{3}{|c|}{ Crude protein $(\%)$} & \multicolumn{3}{|c|}{ Crude protein yield $\left(\mathrm{kg} \mathrm{ha}^{-1}\right)$} \\
\hline & 2009 & 2010 & 2011 & 2009 & 2010 & 2011 \\
\hline Vivar barley & nd & 11.5 & 8.3 & nd & 200 & 408 \\
\hline Murphy oat & 7.2 & 7.3 & 6.2 & 285 & 145 & 245 \\
\hline Pronghorn triticale & 8.5 & 8.4 & 7.5 & 338 & 181 & 320 \\
\hline Cooper pea + Vivar barley & $\mathrm{n} / \mathrm{a}$ & 12.5 & $\mathrm{n} / \mathrm{a}$ & $\mathrm{n} / \mathrm{a}$ & 198 & $\mathrm{n} / \mathrm{a}$ \\
\hline Cooper pea + Murphy oat & $\mathrm{n} / \mathrm{a}$ & 9.7 & $\mathrm{n} / \mathrm{a}$ & $\mathrm{n} / \mathrm{a}$ & 172 & $\mathrm{n} / \mathrm{a}$ \\
\hline Cooper pea + Pronghorn triticale & $\mathrm{n} / \mathrm{a}$ & 9.0 & $\mathrm{n} / \mathrm{a}$ & $\mathrm{n} / \mathrm{a}$ & 155 & $\mathrm{n} / \mathrm{a}$ \\
\hline Tucker pea + Vivar barley & 13.2 & $\mathrm{n} / \mathrm{a}$ & 10.1 & 307 & $\mathrm{n} / \mathrm{a}$ & 395 \\
\hline Tucker pea + Murphy oat & 11.6 & $\mathrm{n} / \mathrm{a}$ & 9.2 & 526 & $\mathrm{n} / \mathrm{a}$ & 309 \\
\hline Tucker pea + Pronghorn triticale & 8.2 & $\mathrm{n} / \mathrm{a}$ & 9.3 & 349 & $\mathrm{n} / \mathrm{a}$ & 324 \\
\hline 40-10 pea + Vivar barley & 11.1 & 12.1 & 11.0 & 290 & 193 & 358 \\
\hline 40-10 peas + Murphy oat & 13.0 & 9.7 & 14.1 & 528 & 193 & 424 \\
\hline 40-10 pea + Pronghorn triticale & 10.3 & 10.8 & 12.0 & 428 & 229 & 401 \\
\hline$L S D_{(0.05)}$ & nd & 1.71 & 2.13 & nd & nd & nd \\
\hline Significance & nd & $* *$ & $* *$ & nd & nd & nd \\
\hline$C V, \%$ & $n d$ & 7.3 & 9.5 & nd & nd & $n d$ \\
\hline
\end{tabular}

Note. $* *$ indicates the treatments effect being significant at 0.01 probability. $\mathrm{n} / \mathrm{a}$ refers to not applicable, because the pea variety was not tested. nd refers to not determined.

The pea + cereal intercrops generally showed improvement in the forage $\mathrm{CP}$ content over respective cereal monocrops in all the three years. Relative to the corresponding monocrops, the increase in CP was significant for the Cooper pea + Murphy oat, 40-10 pea + Murphy oat and 40-10 pea + Pronghorn triticale in 2010; and for the Tucker pea + Murphy oat and all the 3 intercrops of 40-10 pea with cereals in 2011.

The higher forage CP value obtained for most intercrops over monocrops shows the potential protein benefits of peas in intercrops. This shows that pea + cereal intercrops can improve quality of silage or green feed over the monocrop cereals. Increases in forage CP from pea + cereal intercrops over monocrops have been earlier reported for barley and oats in northern Great plains (Carr et al., 2004), and over monocrop barley in central Alberta (Izaurralde et al., 1990; Aasen et al., 2004; Strydhorst et al., 2008).

The higher forage $\mathrm{CP}$ value obtained for most intercrops over monocrops in this study suggests that intercrops of peas and cereals can be offered to beef cattle producers as an alternate method of protein production on the farm. Thus beef producers may be able to substitute part of the grain in cow's diet with forage from appropriate intercrops at their farms. The success of such intercrops have been observed to be highly dependent on the seeding rates for both crops and making sure that there are enough peas in the mixture to influence feed quality (AARD, 2004). Therefore, further research to determine appropriate seeding rates of cereals and peas in the intercrops may be useful to optimize CP improvement with minimum DMY penalty.

The NRC (2000) model for diet of beef cows suggests 7\% CP for maintenance in mid pregnancy, $9 \%$ for a beef cow in late pregnancy, and 11 to $13 \% \mathrm{CP}$ for young (first parity) growing or mature lactating cows. In the present study, all the monocrops (except the Murphy oat in 2011) and intercrops exceeded the 7\% CP for a beef cow in the mid pregnancy stage. But for a beef cow in late pregnancy (third trimester), all monocrop cereals fell short of the $9 \%$ CP (except the Vivar barley in dry year of 2010), while all of the intercrops met this requirement. In addition, most of the intercrops had adequate $\mathrm{CP}(11 \%)$ needed by a young (first parity) growing or mature lactating beef cow.

With few exceptions, pea + cereal intercrops generally increased CPY than the respective cereal monocrops (Table 4). This was because of the increase in CP content in intercrops relative to the corresponding monocrops, in spite of the lower DMY from intercrops than monocrops. Earlier studies have reported increased forage CPY from pea + 
cereal intercrops than the respective monocrops due to high proportion of legumes in DMY (Izaurralde et al., 1990; Aasen et al., 2004; Carr et al., 2004; Strydhorst et al., 2008).

The soluble-CP did not show a consistent change between the monocrops and intercrops (Table 5). The soluble-CP was higher in monocrops of Pronghorn triticale than the other monocrops, but that advantage was not consistent in the intercrops. The ADF-CP tended to be greater in the intercrops than respective monocrops in most cases, particularly in 2009 and 2011, and there was no consistent trend for differences due to a cereal crop or pea variety (Table 5). The UIP-CP did not show consistent influence of the cereal type, pea variety or monocrops versus intercrops.

Table 5. Soluble, ADF and UIP crude protein $(\mathrm{CP})$ concentrations in forage from the cereal monocrops and mixture of pea + cereal intercrops

\begin{tabular}{|c|c|c|c|c|c|c|c|c|c|}
\hline \multirow{2}{*}{ Treatment } & \multicolumn{3}{|c|}{ Soluble-CP (\%) } & \multicolumn{3}{|c|}{ ADF-CP (\%) } & \multicolumn{3}{|c|}{ UIP-CP (\%) } \\
\hline & 2009 & 2010 & 2011 & 2009 & 2010 & 2011 & 2009 & 2010 & 2011 \\
\hline Vivar barley & 44.8 & 54.4 & 42.0 & 0.40 & 0.30 & 0.37 & 37.8 & 25.0 & 25.8 \\
\hline Murphy oat & 46.4 & 56.1 & 42.1 & 0.20 & 0.25 & 0.55 & 29.1 & 26.8 & 30.4 \\
\hline Pronghorn triticale & 53.4 & 68.8 & 50.8 & 0.40 & 0.20 & 0.56 & 29.0 & 18.7 & 23.2 \\
\hline Cooper pea + Vivar barley & $\mathrm{n} / \mathrm{a}$ & 64.6 & $\mathrm{n} / \mathrm{a}$ & $\mathrm{n} / \mathrm{a}$ & 0.25 & $\mathrm{n} / \mathrm{a}$ & $\mathrm{n} / \mathrm{a}$ & 19.8 & $\mathrm{n} / \mathrm{a}$ \\
\hline Cooper pea + Murphy oat & $\mathrm{n} / \mathrm{a}$ & 57.2 & $\mathrm{n} / \mathrm{a}$ & $\mathrm{n} / \mathrm{a}$ & 0.20 & $\mathrm{n} / \mathrm{a}$ & $\mathrm{n} / \mathrm{a}$ & 23.0 & $\mathrm{n} / \mathrm{a}$ \\
\hline Cooper pea + Pronghorn triticale & $\mathrm{n} / \mathrm{a}$ & 63.4 & $\mathrm{n} / \mathrm{a}$ & $\mathrm{n} / \mathrm{a}$ & 0.20 & $\mathrm{n} / \mathrm{a}$ & $\mathrm{n} / \mathrm{a}$ & 20.4 & $\mathrm{n} / \mathrm{a}$ \\
\hline Tucker pea + Vivar barley & 40.6 & $\mathrm{n} / \mathrm{a}$ & 42.5 & 0.60 & $\mathrm{n} / \mathrm{a}$ & 0.53 & 35.2 & $\mathrm{n} / \mathrm{a}$ & 27.2 \\
\hline Tucker pea + Murphy oat & 46.0 & $\mathrm{n} / \mathrm{a}$ & 50.8 & 0.60 & $\mathrm{n} / \mathrm{a}$ & 0.72 & 33.3 & $\mathrm{n} / \mathrm{a}$ & 25.8 \\
\hline Tucker pea + Pronghorn triticale & 51.8 & $\mathrm{n} / \mathrm{a}$ & 48.4 & 0.60 & $\mathrm{n} / \mathrm{a}$ & 0.54 & 31.1 & $\mathrm{n} / \mathrm{a}$ & 21.6 \\
\hline 40-10 pea + Vivar barley & 43.6 & 60.3 & 43.8 & 0.60 & 0.30 & 1.04 & 34.3 & 22.2 & 29.4 \\
\hline 40-10 peas + Murphy oat & 53.0 & 55.9 & 41.0 & 0.50 & 0.20 & 1.16 & 28.5 & 23.5 & 24.2 \\
\hline 40-10 pea + Pronghorn triticale & 49.8 & 65.3 & 49.9 & 0.60 & 0.20 & 1.02 & 32.8 & 19.5 & 23.4 \\
\hline$L S D_{(0.05)}$ & nd & 9.43 & 15.4 & nd & 0.082 & 0.28 & nd & 4.05 & 1.86 \\
\hline Significance & $n d$ & $t$ & $N S$ & nd & $t$ & $* *$ & nd & $*$ & $* *$ \\
\hline$C V, \%$ & $n d$ & 6.7 & 14.6 & $n d$ & 15.2 & 17.1 & $n d$ & 8.0 & 3.14 \\
\hline
\end{tabular}

Note. ${ }^{* *}, *$, and $\mathrm{T}$, indicates the treatments effect being significant at $0.01,0.05$ and 0.10 probability, respectively. NS refers to the treatments effect being not significant at 0.10 probability. $\mathrm{n} / \mathrm{a}$ refers to not applicable, because the pea variety was not tested. nd refers to not determined.

\subsection{Forage Minerals}

\subsubsection{Macro-Minerals}

All the intercrops increased the Ca content in forage over their monocrops, and the increase was significant by most of the intercrops (Table 6). Between the intercrops, the Ca content was greater with the 40-10 pea than with the Cooper or Tucker peas. The Ca content was also greater for treatments with Vivar barley than with Murphy oat or Pronghorn triticale in 2011. The Ca content data indicate potential benefit from intercrops, particularly with the 40-10 forage pea variety. This also suggests that pea variety selection may impact the forage Ca value of pea + cereal intercrops. Higher forage $\mathrm{Ca}$ in the intercrops than their respective monocrops had earlier been observed in US (Carr et al., 2004).

All monocrop cereals and intercrops investigated in the current study had sufficient amounts of Ca $(0.18 \%)$ needed for dry gestating beef cows (NRC, 2000). Forage from none of the monocrops had enough Ca content (0.58\%) to meet the requirement for lactating beef cows. However, all the intercrops with Cooper and 40-10 peas as well as Tucker pea + barley intercrop met and in most cases exceeded the Ca required $(0.58 \%)$ by lactating beef cows. 
Table 6. Calcium and magnesium concentrations in forage from the cereal monocrops and mixture of pea + cereal intercrops

\begin{tabular}{|c|c|c|c|c|c|c|}
\hline \multirow{2}{*}{ Treatment } & \multicolumn{3}{|c|}{ Calcium (\%) } & \multicolumn{3}{|c|}{ Magnesium (\%) } \\
\hline & 2009 & 2010 & 2011 & 2009 & 2010 & 2011 \\
\hline Vivar barley & 0.40 & 0.48 & 0.54 & 0.15 & 0.22 & 0.16 \\
\hline Murphy oat & 0.24 & 0.35 & 0.28 & 0.11 & 0.17 & 0.11 \\
\hline Pronghorn triticale & 0.25 & 0.24 & 0.24 & 0.10 & 0.16 & 0.09 \\
\hline Cooper pea + Vivar barley & $\mathrm{n} / \mathrm{a}$ & 0.63 & $\mathrm{n} / \mathrm{a}$ & $\mathrm{n} / \mathrm{a}$ & 0.23 & $\mathrm{n} / \mathrm{a}$ \\
\hline Cooper pea + Murphy oat & $\mathrm{n} / \mathrm{a}$ & 0.62 & $\mathrm{n} / \mathrm{a}$ & $\mathrm{n} / \mathrm{a}$ & 0.21 & $\mathrm{n} / \mathrm{a}$ \\
\hline Cooper pea + Pronghorn triticale & $\mathrm{n} / \mathrm{a}$ & 0.54 & $\mathrm{n} / \mathrm{a}$ & $\mathrm{n} / \mathrm{a}$ & 0.19 & $\mathrm{n} / \mathrm{a}$ \\
\hline Tucker pea + Vivar barley & 0.60 & $\mathrm{n} / \mathrm{a}$ & 0.59 & 0.19 & $\mathrm{n} / \mathrm{a}$ & 0.16 \\
\hline Tucker pea + Murphy oat & 0.49 & $\mathrm{n} / \mathrm{a}$ & 0.49 & 0.16 & $\mathrm{n} / \mathrm{a}$ & 0.15 \\
\hline Tucker pea + Pronghorn triticale & 0.47 & $\mathrm{n} / \mathrm{a}$ & 0.46 & 0.15 & $\mathrm{n} / \mathrm{a}$ & 0.13 \\
\hline 40-10 pea + Vivar barley & 0.88 & 0.78 & 0.80 & 0.25 & 0.30 & 0.22 \\
\hline 40-10 peas + Murphy oat & 0.72 & 0.78 & 0.92 & 0.20 & 0.28 & 0.23 \\
\hline 40-10 pea + Pronghorn triticale & 0.75 & 0.68 & 0.78 & 0.21 & 0.25 & 0.18 \\
\hline$L S D_{(0.05)}$ & $n d$ & 0.178 & 0.141 & $n d$ & 0.042 & 0.024 \\
\hline Significance & $n d$ & $* *$ & $* *$ & nd & $* *$ & $* *$ \\
\hline$C V, \%$ & nd & 13.6 & 10.9 & nd & 8.2 & 6.6 \\
\hline
\end{tabular}

Note. ${ }^{* *}$ indicates the treatments effect being significant at 0.01 probability. $\mathrm{n} / \mathrm{a}$ refers to not applicable, because the pea variety was not tested. nd refers to not determined.

The Mg content showed a trend that was very similar to the Ca content in forage (Table 6). Significant increases were by the 40-10 pea intercrops with all cereals in 2010 and 2011 and by the Tucker pea intercrops with Murphy oat and Pronghorn triticale in 2011.

The suggested $\mathrm{Mg}$ requirement $(0.12 \% \mathrm{Mg})$ for a dry gestating beef cow was met by all cropping treatments, except for the Murphy oat and Pronghorn triticale monocrops in 2009 (NRC, 2000). The Mg requirement (0.20\%) for a lactating beef cow was met by all the 40-10 intercrops in 3 years, and by the Cooper intercrops with Vivar barley and Murphy oat, and Vivar barley monocrop in 2010.

The $\mathrm{Mg}$ content for the corresponding monocrops and intercrops also tended to be higher in the drier year of 2010 than in 2009 and 2011. What is responsible for higher forage Mg in 2010 than in 2009 and 2011 is difficult to explain. This was despite that soil Mg was about 56\% lower in 2010 than in 2009 and 2011. It is possible that the Mg was tied up in the soil in 2009 and 2011, thereby limiting its uptake by crops in those years.

The forage $\mathrm{P}$ content tended to be improved by intercrops relative to the respective monocrops, but the increase was not always significant (Table 7). The tested cereal type or pea variety also did not consistently influence the $P$ content in forage.

The $\mathrm{P}$ content was strongly influenced by the year, with lower P content in the drier year of 2010 (ranged from 0.05 to $0.10 \%$ ) than both the 2009 and 2011 (ranged from 0.12 to $0.20 \%$ ). Availability of $\mathrm{P}$ is reduced under drier soil conditions due to restricted movement because $\mathrm{P}$ is immobile in soil. Therefore, soil moisture availability needs to be considered when assessing $\mathrm{P}$ level in forage.

Most of the cereal monocrops failed to meet the adequate P level $(0.16 \%)$ suggested for a dry gestating beef cow (NRC, 2000). But the Tucker pea intercrops with Vivar barley and Pronghorn triticale in both 2009 and 2011 plus the 40-10 pea intercrops with Murphy oat in 2011 and with Pronghorn triticale in 2009 and 2011 had adequate $\mathrm{P}(0.16 \% \mathrm{P})$ suggested for a dry gestating beef cow (NRC, 2000). None of the tested treatments had sufficient $\mathrm{P}(0.26 \% \mathrm{P})$ for a lactating beef cow.

The $\mathrm{K}$ content in forage was not consistently different between the cereal types or between the monocrops and their intercrops (Table 7). The $\mathrm{K}$ requirements by different categories of a mature beef cow $(0.6-0.7 \% \mathrm{~K})$ were met by all investigated treatments. 
Table 7. Phosphorus and potassium concentrations of forage from the cereal monocrops and mixture of pea + cereal intercrops

\begin{tabular}{|c|c|c|c|c|c|c|}
\hline \multirow{2}{*}{ Treatment } & \multicolumn{3}{|c|}{ Phosphorus (\%) } & \multicolumn{3}{|c|}{ Potassium (\%) } \\
\hline & 2009 & 2010 & 2011 & 2009 & 2010 & 2011 \\
\hline Vivar barley & 0.16 & 0.07 & 0.14 & 1.69 & 1.53 & 1.46 \\
\hline Murphy oat & 0.12 & 0.05 & 0.12 & 1.65 & 1.49 & 1.86 \\
\hline Pronghorn triticale & 0.14 & 0.06 & 0.16 & 1.51 & 1.19 & 1.52 \\
\hline Cooper pea + Vivar barley & $\mathrm{n} / \mathrm{a}$ & 0.07 & $\mathrm{n} / \mathrm{a}$ & $\mathrm{n} / \mathrm{a}$ & 1.34 & $\mathrm{n} / \mathrm{a}$ \\
\hline Cooper pea + Murphy oat & $\mathrm{n} / \mathrm{a}$ & 0.08 & $\mathrm{n} / \mathrm{a}$ & $\mathrm{n} / \mathrm{a}$ & 1.22 & $\mathrm{n} / \mathrm{a}$ \\
\hline Cooper pea + Pronghorn triticale & $\mathrm{n} / \mathrm{a}$ & 0.08 & $\mathrm{n} / \mathrm{a}$ & $\mathrm{n} / \mathrm{a}$ & 1.04 & $\mathrm{n} / \mathrm{a}$ \\
\hline Tucker pea + Vivar barley & 0.17 & $\mathrm{n} / \mathrm{a}$ & 0.16 & 2.00 & $\mathrm{n} / \mathrm{a}$ & 1.44 \\
\hline Tucker pea + Murphy oat & 0.15 & $\mathrm{n} / \mathrm{a}$ & 0.14 & 1.64 & $\mathrm{n} / \mathrm{a}$ & 2.01 \\
\hline Tucker pea + Pronghorn triticale & 0.16 & $\mathrm{n} / \mathrm{a}$ & 0.16 & 1.52 & $\mathrm{n} / \mathrm{a}$ & 1.80 \\
\hline 40-10 pea + Vivar barley & 0.14 & 0.06 & 0.14 & 1.91 & 1.32 & 1.56 \\
\hline 40-10 peas + Murphy oat & 0.15 & 0.10 & 0.20 & 1.52 & 1.32 & 1.75 \\
\hline 40-10 pea + Pronghorn triticale & 0.16 & 0.10 & 0.18 & 1.44 & 1.08 & 1.62 \\
\hline$L S D_{(0.05)}$ & nd & 0.049 & 0.027 & nd & 0.226 & 0.370 \\
\hline Significance & nd & $N S$ & $* *$ & nd & $*$ & $t$ \\
\hline$C V, \%$ & $n d$ & 28.1 & 7.6 & $n d$ & 7.6 & 9.6 \\
\hline
\end{tabular}

Note. ${ }^{* *},{ }^{*}$, and $\uparrow$, indicates the treatments effect being significant at $0.01,0.05$ and 0.10 probability, respectively. NS refers to the treatments effect being not significant at 0.10 probability. $\mathrm{n} / \mathrm{a}$ refers to not applicable, because the pea variety was not tested. nd refers to not determined.

Similar to the K content, the $\mathrm{S}$ content in forage was not consistently different between the cereal types or between the monocrops and their intercrops (Table 8). Except for monocrops of Pronghorn triticale and Murphy oats, the $\mathrm{S}$ requirement for a mature beef cow $(0.15 \% \mathrm{~S})$ would be met by all cropping treatments tested (NRC, 2000).

The main difference in forage Na content was higher level in all the treatments with Murphy oat than the other 2 cereals (Table 8). Intercrops did not show a consistent influence on the Na content compared to their monocrops. The higher forage $\mathrm{Na}$ content with oat compared to barley and triticale from the monocrops as well as the intercrops in the present study further confirms and extends the findings of Gill et al. (2013a, 2013b) and Gill and Omokanye (2016). Their evaluation of barley, oat and triticale for silage production in the same environment, showed that forage from oats had up to $0.24 \%$ more $\mathrm{Na}$ than from barley or triticale. The suggested $0.10 \% \mathrm{Na}$ level for a mature beef cow by NRC (2000) would be met by both the monocrops and intercrops of Murphy oat while none of the other tested systems will satisfy this requirement.

The results show that all macro-minerals requirements for different beef cow categories will not be met by some of the monocrops or intercrops investigated. Therefore, some form of mineral supplementation strategy is needed to address the short fall of some macro-minerals for some beef cow categories, particularly for $\mathrm{Ca}, \mathrm{P}$ and $\mathrm{Na}$. Use of appropriate intercrops may be useful to minimize supplementary needs for $\mathrm{Ca}, \mathrm{Mg}$ and $\mathrm{P}$. 
Table 8. Sulphur and sodium concentrations in forage from the cereal monocrops and mixture of pea + cereal intercrops

\begin{tabular}{|c|c|c|c|c|c|c|}
\hline \multirow{2}{*}{ Treatment } & \multicolumn{3}{|c|}{ Sulphur (\%) } & \multicolumn{3}{|c|}{ Sodium (\%) } \\
\hline & 2009 & 2010 & 2011 & 2009 & 2010 & 2011 \\
\hline Vivar barley & 0.14 & 0.20 & 0.16 & 0.07 & 0.18 & 0.06 \\
\hline Murphy oat & 0.14 & 0.15 & 0.14 & 0.25 & 0.24 & 0.32 \\
\hline Pronghorn triticale & 0.11 & 0.14 & 0.12 & 0.02 & 0.06 & 0.04 \\
\hline Cooper pea + Vivar barley & $\mathrm{n} / \mathrm{a}$ & 0.16 & $\mathrm{n} / \mathrm{a}$ & $\mathrm{n} / \mathrm{a}$ & 0.10 & $\mathrm{n} / \mathrm{a}$ \\
\hline Cooper pea + Murphy oat & $\mathrm{n} / \mathrm{a}$ & 0.18 & $\mathrm{n} / \mathrm{a}$ & $\mathrm{n} / \mathrm{a}$ & 0.16 & $\mathrm{n} / \mathrm{a}$ \\
\hline Cooper pea + Pronghorn triticale & $\mathrm{n} / \mathrm{a}$ & 0.16 & $\mathrm{n} / \mathrm{a}$ & $\mathrm{n} / \mathrm{a}$ & 0.04 & $\mathrm{n} / \mathrm{a}$ \\
\hline Tucker pea + Vivar barley & 0.18 & $\mathrm{n} / \mathrm{a}$ & 0.16 & 0.07 & $\mathrm{n} / \mathrm{a}$ & 0.06 \\
\hline Tucker pea + Murphy oat & 0.15 & $\mathrm{n} / \mathrm{a}$ & 0.17 & 0.14 & $\mathrm{n} / \mathrm{a}$ & 0.32 \\
\hline Tucker pea + Pronghorn triticale & 0.14 & $\mathrm{n} / \mathrm{a}$ & 0.16 & 0.03 & $\mathrm{n} / \mathrm{a}$ & 0.04 \\
\hline 40-10 pea + Vivar barley & 0.15 & 0.16 & 0.15 & 0.07 & 0.10 & 0.08 \\
\hline 40-10 peas + Murphy oat & 0.13 & 0.16 & 0.18 & 0.11 & 0.16 & 0.16 \\
\hline 40-10 pea + Pronghorn triticale & 0.14 & 0.16 & 0.18 & 0.02 & 0.04 & 0.04 \\
\hline$L S D_{(0.05)}$ & $n d$ & 0.031 & 0.045 & $n d$ & 0.048 & 0.054 \\
\hline Significance & nd & $T$ & NS & nd & $* *$ & $* *$ \\
\hline$C V, \%$ & nd & 8.2 & 12.4 & nd & 17.4 & 18.3 \\
\hline
\end{tabular}

Note. ${ }^{* *}$ and $\uparrow$ indicates the treatments effect being significant at 0.05 and 0.10 probability, respectively. NS refers to the treatments effect being not significant at 0.10 probability. $\mathrm{n} / \mathrm{a}$ refers to not applicable, because the pea variety was not tested. nd refers to not determined.

\subsubsection{Trace-Minerals}

There appeared no consistent trend in forage $\mathrm{Cu}$ content differences between the monocrops and their respective intercrops (Table 9). Vivar barley monocrop and its intercrops seemed to have higher forage $\mathrm{Cu}$ values than the other monocrops as well as intercrops, with no consistent trend between the Murphy oat and Pronghorn triticale systems. Most of the cropping treatments examined here would be unable to meet the $\mathrm{Cu}$ requirement (10 ppm) of a mature beef cow (NRC, 2000).

Table 9. Copper and zinc concentrations in forage from the cereal monocrops and mixture of pea + cereal intercrops

\begin{tabular}{|c|c|c|c|c|c|c|}
\hline \multirow{2}{*}{ Treatment } & \multicolumn{3}{|c|}{ Copper (ppm) } & \multicolumn{3}{|c|}{ Zinc (ppm) } \\
\hline & 2009 & 2010 & 2011 & 2009 & 2010 & 2011 \\
\hline Vivar barley & 11.2 & 10.0 & 7.45 & 23.9 & 40.45 & 30.0 \\
\hline Murphy oat & 10.2 & 9.7 & 3.8 & 18.2 & 23.7 & 21.9 \\
\hline Pronghorn triticale & 6.2 & 11.5 & 5.9 & 25.7 & 31.7 & 30.4 \\
\hline Cooper pea + Vivar barley & $\mathrm{n} / \mathrm{a}$ & 7.8 & $\mathrm{n} / \mathrm{a}$ & $\mathrm{n} / \mathrm{a}$ & 38.5 & $\mathrm{n} / \mathrm{a}$ \\
\hline Cooper pea + Murphy oat & $\mathrm{n} / \mathrm{a}$ & 7.7 & $\mathrm{n} / \mathrm{a}$ & $\mathrm{n} / \mathrm{a}$ & 31.7 & $\mathrm{n} / \mathrm{a}$ \\
\hline Cooper pea + Pronghorn triticale & $\mathrm{n} / \mathrm{a}$ & 9.6 & $\mathrm{n} / \mathrm{a}$ & $\mathrm{n} / \mathrm{a}$ & 34.9 & $\mathrm{n} / \mathrm{a}$ \\
\hline Tucker pea + Vivar barley & 8.8 & $\mathrm{n} / \mathrm{a}$ & 7.8 & 33.2 & $\mathrm{n} / \mathrm{a}$ & 33.5 \\
\hline Tucker pea + Murphy oat & 5.7 & $\mathrm{n} / \mathrm{a}$ & 5.0 & 25.7 & $\mathrm{n} / \mathrm{a}$ & 24.5 \\
\hline Tucker pea + Pronghorn triticale & 7.4 & $\mathrm{n} / \mathrm{a}$ & 6.2 & 29.9 & $\mathrm{n} / \mathrm{a}$ & 32.9 \\
\hline 40-10 pea + Vivar barley & 10.4 & 9.6 & 9.6 & 33.7 & 36.9 & 41.9 \\
\hline 40-10 peas + Murphy oat & 6.0 & 7.6 & 7.0 & 27.3 & 30.4 & 33.6 \\
\hline 40-10 pea + Pronghorn triticale & 6.7 & 8.4 & 7.0 & 32.1 & 31.8 & 32.0 \\
\hline$L S D_{(0.05)}$ & nd & 3.77 & 0.67 & nd & 7.17 & 4.74 \\
\hline Significance & $n d$ & $N S$ & $* *$ & $n d$ & $*$ & $* *$ \\
\hline$C V, \%$ & nd & 18.0 & 4.4 & $n d$ & 9.3 & 6.6 \\
\hline
\end{tabular}

Note. $* *$ and $*$ indicates the treatments effect being significant at 0.01 and 0.05 probability, respectively. NS refers to the treatments effect being not significant at 0.10 probability. $\mathrm{n} / \mathrm{a}$ refers to not applicable, because the pea variety was not tested. nd refers to not determined. 
There appeared to be a tendency for higher $\mathrm{Zn}$ content in the intercrops than respective monocrops (except for the Vivar barley intercrops in 2010), but the increase by most intercrops was not significant (Table 9). Also there was a trend for $\mathrm{Zn}$ content in forage to be Vivar barley $>$ Pronghorn triticale $>$ Murphy oat systems. However, the differences due to cereal type also were not significant in most cases.

Regarding meeting the suggested $\mathrm{Zn}$ requirement (30 ppm) of a mature beef cow (NRC, 2000), all the intercrops of Cooper pea in 2010, and 40-10 pea in 3 years (except for 40-10 pea + Murphy oat in 2009) as well as some of the Tucker pea intercrops had enough Zn levels. Monocrops of only Vivar barley and Pronghorn triticale in 2010 and 2011 had enough $\mathrm{Zn}$ content to meet the $\mathrm{Zn}$ needs of a mature beef cow.

There was no consistent trend for treatment effects on the Fe content in forage and there was high variability in the data (Table 10). All monocrop cereals and intercrops far exceeded the Fe requirement (50 ppm) for a mature beef cow (NRC, 2000).

With respect to Mn content in forage, the treatment effect was not significant in both 2010 and 2011 (Table 10). Main noticeable effect was much higher Mn values in dry year of 2010 (range 86 to $102 \mathrm{ppm}$ ) than in 2011 with more rain (range 26.6 to $51.2 \mathrm{ppm}$ ). All treatments had much higher than the suggested $40 \mathrm{ppm} \mathrm{Mn}$ requirement (NRC, 2000) by a mature beef cow in 2010 (dry year) while most of the treatments in 2011 fell short of this suggested level.

As with macro-minerals, some form of trace-mineral supplementation would be needed to address the short fall of $\mathrm{Cu}, \mathrm{Zn}$ and $\mathrm{Mn}$ for mature beef cattle in some situations. Like $\mathrm{Ca}, \mathrm{Mg}$ and $\mathrm{P}$, use of appropriate intercrops may be useful to minimize supplementary needs for $\mathrm{Zn}$.

Table 10. Iron and manganese concentrations in forage from the cereal monocrops and mixture of pea + cereal intercrops

\begin{tabular}{|c|c|c|c|c|c|c|}
\hline \multirow{2}{*}{ Treatment } & \multicolumn{3}{|c|}{ Iron (ppm) } & \multicolumn{3}{|c|}{ Manganese (ppm) } \\
\hline & 2009 & 2010 & 2011 & 2009 & 2010 & 2011 \\
\hline Vivar barley & 101 & 986 & 314 & nd & 102 & 26.6 \\
\hline Murphy oat & 292 & 631 & 101 & nd & 102 & 36.1 \\
\hline Pronghorn triticale & 166 & 466 & 109 & nd & 92 & 35.1 \\
\hline Cooper pea + Vivar barley & $\mathrm{n} / \mathrm{a}$ & 743 & $\mathrm{n} / \mathrm{a}$ & nd & 86 & $\mathrm{n} / \mathrm{a}$ \\
\hline Cooper pea + Murphy oat & $\mathrm{n} / \mathrm{a}$ & 705 & $\mathrm{n} / \mathrm{a}$ & nd & 93 & $\mathrm{n} / \mathrm{a}$ \\
\hline Cooper pea + Pronghorn triticale & $\mathrm{n} / \mathrm{a}$ & 523 & $\mathrm{n} / \mathrm{a}$ & nd & 90 & $\mathrm{n} / \mathrm{a}$ \\
\hline Tucker pea + Vivar barley & 277 & $\mathrm{n} / \mathrm{a}$ & 368 & nd & $\mathrm{n} / \mathrm{a}$ & 28.3 \\
\hline Tucker pea + Murphy oat & 251 & $\mathrm{n} / \mathrm{a}$ & 165 & nd & $\mathrm{n} / \mathrm{a}$ & 39.0 \\
\hline Tucker pea + Pronghorn triticale & 145 & $\mathrm{n} / \mathrm{a}$ & 101 & nd & $\mathrm{n} / \mathrm{a}$ & 37.7 \\
\hline 40-10 pea + Vivar barley & 681 & 728 & 675 & nd & 96 & 51.2 \\
\hline 40-10 peas + Murphy oat & 150 & 765 & 344 & nd & 100 & 46.7 \\
\hline 40-10 pea + Pronghorn triticale & 273 & 657 & 129 & nd & 92 & 36.8 \\
\hline$L S D_{(0.05)}$ & $n d$ & 671.5 & 315.2 & $n d$ & 18.47 & 18.80 \\
\hline Significance & $n d$ & $N S$ & $*$ & nd & $N S$ & $N S$ \\
\hline$C V, \%$ & $n d$ & 42.2 & 53.4 & $n d$ & 8.4 & 21.7 \\
\hline
\end{tabular}

Note. $*$ indicates the treatments effect being significant at 0.05 probability. NS refers to the treatments effect being not significant at 0.10 probability. $\mathrm{n} / \mathrm{a}$ refers to not applicable, because the pea variety was not tested. nd refers to not determined.

\subsection{Forage Detergent Fibers}

The forage ADF and NDF were both significantly affected by the cropping treatments examined (Table 11). The intercrops did not show a consistent change for the ADF and NDF contents relative to the respective monocrops. Murphy oat had higher forage ADF and NDF values than Vivar barley and Pronghorn triticale as their monocrops, with a similar trend for their intercrops with Cooper pea. But for the Tucker pea and 40-10 pea intercrops, there was no consistent trend in favour of any cereal crop. Another noticeable point was lower ADF and NDF values in the dry year of 2010 compared to other 2 years. Our results disagree with decline in the ADF 
and NDF contents in barley-legume intercrops relative to the respective monocrops observed in central Alberta (Aasen et al., 2004; Strydhorst et al., 2008).

The NDF and ADF are both negatively related to forage quality. NDF is a predictor of voluntary intake because it provides bulk or fill, and ADF is the least digestible plant components including cellulose and lignin. In general, low NDF and ADF values are desired. Consistently higher ADF and NDF values of the Murphy oat treatments than the Pronghorn triticale and Vivar barley treatments suggest that when all the monocrop cereals varieties are presented side by side to cows in a preference study, there may be a tendency that Murphy oats would likely be less preferred and consumed less than Pronghorn triticale and Vivar barley. For the intercrops, there appeared to be inconsistencies in the ADF and NDF values obtained.

Table 11. Acid detergent (ADF) and neutral detergent (NDF) fibre concentrations in forage from the cereal monocrops and mixture of pea + cereal intercrops

\begin{tabular}{|c|c|c|c|c|c|c|}
\hline \multirow{2}{*}{ Treatment } & \multicolumn{3}{|c|}{$\mathrm{ADF}(\%)$} & \multicolumn{3}{|c|}{ NDF (\%) } \\
\hline & 2009 & 2010 & 2011 & 2009 & 2010 & 2011 \\
\hline Vivar barley & 35.4 & 28.5 & 29.7 & 55.0 & 47.9 & 45.08 \\
\hline Murphy oat & 45.2 & 37.0 & 42.9 & 63.6 & 58.6 & 62.46 \\
\hline Pronghorn triticale & 40.4 & 29.0 & 35.3 & 53.8 & 47.1 & 52.76 \\
\hline Cooper pea + Vivar barley & $\mathrm{n} / \mathrm{a}$ & 29.6 & $\mathrm{n} / \mathrm{a}$ & $\mathrm{n} / \mathrm{a}$ & 42.9 & $\mathrm{n} / \mathrm{a}$ \\
\hline Cooper pea + Murphy oat & $\mathrm{n} / \mathrm{a}$ & 31.9 & $\mathrm{n} / \mathrm{a}$ & $\mathrm{n} / \mathrm{a}$ & 48.9 & $\mathrm{n} / \mathrm{a}$ \\
\hline Cooper pea + Pronghorn triticale & $\mathrm{n} / \mathrm{a}$ & 28.6 & $\mathrm{n} / \mathrm{a}$ & $\mathrm{n} / \mathrm{a}$ & 44.8 & $\mathrm{n} / \mathrm{a}$ \\
\hline Tucker pea + Vivar barley & 42.8 & $\mathrm{n} / \mathrm{a}$ & 30.2 & 56.0 & $\mathrm{n} / \mathrm{a}$ & 46.6 \\
\hline Tucker pea + Murphy oat & 42.2 & $\mathrm{n} / \mathrm{a}$ & 43.3 & 55.2 & $\mathrm{n} / \mathrm{a}$ & 59.6 \\
\hline Tucker pea + Pronghorn triticale & 34.0 & $\mathrm{n} / \mathrm{a}$ & 34.8 & 54.0 & $\mathrm{n} / \mathrm{a}$ & 50.0 \\
\hline 40-10 pea + Vivar barley & 43.0 & 28.9 & 41.8 & 58.0 & 42.9 & 55.5 \\
\hline 40-10 peas + Murphy oat & 37.8 & 31.9 & 38.1 & 49.4 & 51.2 & 50.8 \\
\hline 40-10 pea + Pronghorn triticale & 37.0 & 28.7 & 36.3 & 49.8 & 42.5 & 48.5 \\
\hline$L S D_{(0.05)}$ & $n d$ & 2.45 & 4.09 & $n d$ & 3.58 & 5.86 \\
\hline Significance & $n d$ & $* *$ & $* *$ & $n d$ & $* *$ & $* *$ \\
\hline$C V, \%$ & $n d$ & 3.5 & 4.8 & $n d$ & 3.3 & 4.8 \\
\hline
\end{tabular}

Note. $* *$ indicates the treatments effect being significant at 0.01 probability. $\mathrm{n} / \mathrm{a}$ refers to not applicable, because the pea variety was not tested. nd refers to not determined.

\subsection{Forage Energy}

Energy is probably the most important nutritional consideration in beef cattle production in cold climates. Energy gives the ability to use the building blocks for growth and other productive purposes.

Twelve (12) of the 18 intercrops improved TDN content in forage over their monocrops (Table 12). Murphy oat had lower forage TDN content than Vivar barley and Pronghorn triticale in their monocrops, and in their intercrops with Cooper pea. But for the Tucker pea and 40-10 pea intercrops, there was no consistent trend in favour of any cereal crop. The TDN values in the dry year of 2010 were higher compared to other 2 years. 
Table 12. Total digestive nutrients concentration (TDN) and yield (TDNY) for forage from the cereal monocrops and mixture of pea + cereal intercrops

\begin{tabular}{|c|c|c|c|c|c|c|}
\hline \multirow{2}{*}{ Treatment } & \multicolumn{3}{|c|}{ TDN (\%) } & \multicolumn{3}{|c|}{ TDNY $\left(\mathrm{kg} \mathrm{ha}^{-1}\right)$} \\
\hline & 2009 & 2010 & 2011 & 2009 & 2010 & 2011 \\
\hline Vivar barley & 61.3 & 66.7 & 65.8 & 1761 & 1164 & 3227 \\
\hline Murphy oat & 53.7 & 60.1 & 55.5 & 2132 & 1193 & 2210 \\
\hline Pronghorn triticale & 57.4 & 66.3 & 61.4 & 2283 & 1434 & 2619 \\
\hline Cooper pea + Vivar barley & $\mathrm{n} / \mathrm{a}$ & 65.8 & $\mathrm{n} / \mathrm{a}$ & $\mathrm{n} / \mathrm{a}$ & 1045 & $\mathrm{n} / \mathrm{a}$ \\
\hline Cooper pea + Murphy oat & $\mathrm{n} / \mathrm{a}$ & 64.0 & $\mathrm{n} / \mathrm{a}$ & $\mathrm{n} / \mathrm{a}$ & 1137 & $\mathrm{n} / \mathrm{a}$ \\
\hline Cooper pea + Pronghorn triticale & $\mathrm{n} / \mathrm{a}$ & 66.6 & $\mathrm{n} / \mathrm{a}$ & $\mathrm{n} / \mathrm{a}$ & 1149 & $\mathrm{n} / \mathrm{a}$ \\
\hline Tucker pea + Vivar barley & 55.6 & $\mathrm{n} / \mathrm{a}$ & 65.4 & 1292 & $\mathrm{n} / \mathrm{a}$ & 2551 \\
\hline Tucker pea + Murphy oat & 56.0 & $\mathrm{n} / \mathrm{a}$ & 55.2 & 2540 & $\mathrm{n} / \mathrm{a}$ & 1850 \\
\hline Tucker pea + Pronghorn triticale & 62.4 & $\mathrm{n} / \mathrm{a}$ & 61.8 & 2661 & $\mathrm{n} / \mathrm{a}$ & 2157 \\
\hline 40-10 pea + Vivar barley & 55.4 & 66.4 & 56.3 & 1491 & 1062 & 1840 \\
\hline 40-10 peas + Murphy oat & 59.5 & 64.0 & 59.2 & 2418 & 1278 & 1777 \\
\hline 40-10 pea + Pronghorn triticale & 60.1 & 66.6 & 60.6 & 2498 & 1410 & 2029 \\
\hline$L S D_{(0.05)}$ & $n d$ & 1.91 & 3.19 & $n d$ & $n d$ & $n d$ \\
\hline Significance & nd & $* *$ & $* *$ & nd & nd & nd \\
\hline$C V, \%$ & nd & 1.3 & 2.3 & nd & nd & nd \\
\hline
\end{tabular}

Note. ${ }^{* *}$ indicates the treatments effect being significant at 0.01 probability. $\mathrm{n} / \mathrm{a}$ refers to not applicable, because the pea variety was not tested. nd refers to not determined.

For total digestible nutrients (TDN), the Rule of Thumb is $55-60-65 \%$ (Yurchuk \& Okine, 2004). This rule states that for a mature beef cow to maintain her body condition score (BCS) through winter, the ration must have a TDN energy reading of $55 \%$ for mid pregnancy period, $60 \%$ for late pregnancy period and $65 \%$ after calving. All monocrop cereals as well as their intercrops had sufficient TDN content for a dry gestating beef cow in the mid-pregnancy stage, except for the Murphy oat monocrop in 2009. For a beef cow in the late-pregnancy stage, monocrops of Vivar barley in all 3 years, Pronghorn triticale in 2010 and 2011 and Murphy oat in 2010 met the $60 \%$ TDN requirement. From the 18 intercrops, all six in 2010, 3 in 2011 and 2 in 2009 (11 total) met the 60\% requirement. Some of the monocrops (barley in 2010 and 2011 plus Pronghorn triticale in 2010), and 5 intercrops (Cooper pea and 40-10 pea intercrops with Vivar barley and Pronghorn triticale in 2010, and Tucker pea + Vivar barley in 2011) had adequate TDN $(65 \%)$ required by a lactating beef cow.

The total digestible nutrients yield (TDNY) usually indicated a decline with intercrops compared to their monocrops (Table 12). This was apparently due to DMY for the intercrops relative to respective intercrops.

The intercrops did not change the forage $\mathrm{NE}_{\mathrm{L}}, \mathrm{NE}_{\mathrm{M}}$ and $\mathrm{NE}_{\mathrm{G}}$ values relative to the respective monocrops (Table 13). The forage $\mathrm{NE}_{\mathrm{L}}, \mathrm{NE}_{\mathrm{M}}$ and $\mathrm{NE}_{\mathrm{G}}$ levels were lower for the Murphy oat than other 2 monocrops. Three year averages for the Murphy oat, Vivar barely and Pronghorn triticale monocrops, respectively, were 1.27, 1.39 and $1.47 \mathrm{Mcal} \mathrm{kg}{ }^{-1}$ of $\mathrm{NE}_{\mathrm{L}}, 1.35,150$ and $159 \mathrm{Mcal} \mathrm{kg}^{-1}$ of $\mathrm{NE}_{\mathrm{M}}$, and $0.63,0.78$ and $0.86 \mathrm{Mcal} \mathrm{kg}^{-1}$ of $\mathrm{NE}_{\mathrm{G}}$. Unlike the monocrops, there was no consistent effect of the cereal types or pea varieties on the forage $\mathrm{NE}_{\mathrm{L}}, \mathrm{NE}_{\mathrm{M}}$ and $\mathrm{NE}_{\mathrm{G}}$ values in the intercrops. Apparently the effect of cereal type on the forage $\mathrm{NE}_{\mathrm{L}}, \mathrm{NE}_{\mathrm{M}}$ and $\mathrm{NE}_{\mathrm{G}}$ values was reduced due to lower proportion of these cereals in the intercrops. Similar to the TDN results, the forage $\mathrm{NE}_{\mathrm{L}}$, $\mathrm{NE}_{\mathrm{M}}$ and $\mathrm{NE}_{\mathrm{G}}$ values were higher in the dry year of 2010 compared to other 2 years.

All monocrops and intercrops exceeded the 1.19-1.28 $\mathrm{MCal} \mathrm{kg}^{-1} \mathrm{NE}_{\mathrm{M}}$ level suggested for a mature beef cow (NRC, 2000). Also, all monocrop cereals and intercrops were within the suggested $\mathrm{NE}_{\mathrm{G}}$ level (0.53-1.37 MCal $\mathrm{kg}^{-1} \mathrm{NE}_{\mathrm{G}}$ ) for the young beef cattle. 
Table 13. Lactation $\left(\mathrm{NE}_{\mathrm{L}}\right)$, maintain $\left(\mathrm{NE}_{\mathrm{M}}\right)$ and gain $\left(\mathrm{NE}_{\mathrm{G}}\right)$ forms of net energy for forage from the cereal monocrops and mixture of pea + cereal intercrops

\begin{tabular}{|c|c|c|c|c|c|c|c|c|c|}
\hline \multirow{2}{*}{ Treatment } & \multicolumn{3}{|c|}{$\mathrm{NE}_{\mathrm{L}}\left(\mathrm{Mcal} \mathrm{kg}{ }^{-1}\right)$} & \multicolumn{3}{|c|}{$\mathrm{NE}_{\mathrm{M}}\left(\right.$ Mcal kg$\left.{ }^{-1}\right)$} & \multicolumn{3}{|c|}{$\mathrm{NE}_{\mathrm{G}}\left(\mathrm{Mcal} \mathrm{kg}^{-1}\right)$} \\
\hline & 2009 & 2010 & 2011 & 2009 & 2010 & 2011 & 2009 & 2010 & 2011 \\
\hline Vivar barley & 1.39 & 1.52 & 1.50 & 1.49 & 1.65 & 1.62 & 0.77 & 0.92 & 0.90 \\
\hline Murphy oat & 1.20 & 1.36 & 1.24 & 1.27 & 1.46 & 1.32 & 0.55 & 0.74 & 0.60 \\
\hline Pronghorn triticale & 1.29 & 1.51 & 1.38 & 1.38 & 1.64 & 1.49 & 0.66 & 0.92 & 0.77 \\
\hline Cooper pea + Vivar barley & $\mathrm{n} / \mathrm{a}$ & 1.50 & $\mathrm{n} / \mathrm{a}$ & $\mathrm{n} / \mathrm{a}$ & 1.62 & $\mathrm{n} / \mathrm{a}$ & $\mathrm{n} / \mathrm{a}$ & 0.90 & $\mathrm{n} / \mathrm{a}$ \\
\hline Cooper pea + Murphy oat & $\mathrm{n} / \mathrm{a}$ & 1.46 & $\mathrm{n} / \mathrm{a}$ & $\mathrm{n} / \mathrm{a}$ & 1.57 & $\mathrm{n} / \mathrm{a}$ & $\mathrm{n} / \mathrm{a}$ & 0.84 & $\mathrm{n} / \mathrm{a}$ \\
\hline Cooper pea + Pronghorn triticale & $\mathrm{n} / \mathrm{a}$ & 1.52 & $\mathrm{n} / \mathrm{a}$ & $\mathrm{n} / \mathrm{a}$ & 1.64 & $\mathrm{n} / \mathrm{a}$ & $\mathrm{n} / \mathrm{a}$ & 0.92 & $\mathrm{n} / \mathrm{a}$ \\
\hline Tucker pea + Vivar barley & 1.25 & $\mathrm{n} / \mathrm{a}$ & 1.49 & 1.32 & $\mathrm{n} / \mathrm{a}$ & 1.61 & 0.60 & $\mathrm{n} / \mathrm{a}$ & 0.88 \\
\hline Tucker pea + Murphy oat & 1.26 & $\mathrm{n} / \mathrm{a}$ & 1.24 & 1.34 & $\mathrm{n} / \mathrm{a}$ & 1.31 & 0.62 & $\mathrm{n} / \mathrm{a}$ & 0.59 \\
\hline Tucker pea + Pronghorn triticale & 1.41 & $\mathrm{n} / \mathrm{a}$ & 1.40 & 1.52 & $\mathrm{n} / \mathrm{a}$ & 1.50 & 0.80 & $\mathrm{n} / \mathrm{a}$ & 0.78 \\
\hline 40-10 pea + Vivar barley & 1.24 & 1.51 & 1.26 & 1.32 & 1.64 & 1.34 & 0.60 & 0.92 & 0.62 \\
\hline 40-10 peas + Murphy oat & 1.34 & 1.45 & 1.34 & 1.44 & 1.57 & 1.43 & 0.72 & 0.85 & 0.70 \\
\hline $40-10$ pea + Pronghorn triticale & 1.36 & 1.52 & 1.37 & 1.46 & 1.64 & 1.47 & 0.73 & 0.92 & 0.75 \\
\hline$L S D_{(0.05)}$ & $n d$ & 0.05 & 0.08 & $n d$ & 0.05 & 0.09 & $n d$ & 0.06 & 0.09 \\
\hline Significance & nd & $* *$ & $* *$ & nd & $* *$ & $* *$ & nd & $* *$ & $* *$ \\
\hline$C V, \%$ & nd & 1.4 & 2.7 & nd & 1.4 & 2.8 & nd & 2.9 & 5.4 \\
\hline
\end{tabular}

Note. ${ }^{* *}$ indicates the treatments effect being significant at 0.01 probability. $\mathrm{n} / \mathrm{a}$ refers to not applicable, because the pea variety was not tested. nd refers to not determined.

\subsection{Relative Feed Value (RFV) and Non Fibre Carbohydrate (NFC)}

The RFV is an index that is used to predict the consumption and energy value of the forages and it is derived from the digestible dry matter (DDM) and dry matter intake (DMI). Similar to the trends for TDN, $\mathrm{NE}_{\mathrm{L}}, \mathrm{NE}_{\mathrm{M}}$ and $\mathrm{NE}_{\mathrm{G}}$ values, the RFV was lower for the Murphy oat than other 2 monocrops, and intercrops did not change the RFV values compare to the respective monocrops (Table 14). Unlike current study, Strydhorst et al. (2008) observed higher RFV values for barley + legume intercrops than the barley monocrop, and attributed RFV increase to decline in NDF and ADF contents of the barley-legume intercrops. Using the suggested RFVs for beef cows (90-115 RFV) by Schroeder (1996), most of the tested systems were well within the range, except the Murphy oat monocrop and tucker pea + Murphy oat intercrop in 2011 had lower RFV than 90.

The NFC values of different cropping systems showed a similar trend as the RFV values (Table 14).

Table 14. Relative feed value (RFV) and non fibre carbohydrate (NFC) concentration for forage from the cereal monocrops and mixture of pea + cereal intercrops

\begin{tabular}{|c|c|c|c|c|c|c|}
\hline \multirow{2}{*}{ Treatment } & \multicolumn{3}{|c|}{ RFV (\%) } & \multicolumn{3}{|c|}{ NFC (\%) } \\
\hline & 2009 & 2010 & 2011 & 2009 & 2010 & 2011 \\
\hline Vivar barley & nd & 130 & 138 & nd & 27.6 & 35.1 \\
\hline Murphy oat & nd & 95 & 83 & nd & 22.6 & 19.9 \\
\hline Pronghorn triticale & nd & 131 & 108 & nd & 33.0 & 28.2 \\
\hline Cooper pea + Vivar barley & nd & 143 & $\mathrm{n} / \mathrm{a}$ & nd & 33.1 & $\mathrm{n} / \mathrm{a}$ \\
\hline Cooper pea + Murphy oat & nd & 122 & $\mathrm{n} / \mathrm{a}$ & nd & 29.9 & $\mathrm{n} / \mathrm{a}$ \\
\hline Cooper pea + Pronghorn triticale & nd & 138 & $\mathrm{n} / \mathrm{a}$ & nd & 34.7 & $\mathrm{n} / \mathrm{a}$ \\
\hline Tucker pea + Vivar barley & nd & $\mathrm{n} / \mathrm{a}$ & 130 & nd & $\mathrm{n} / \mathrm{a}$ & 31.8 \\
\hline Tucker pea + Murphy oat & nd & $\mathrm{n} / \mathrm{a}$ & 86 & nd & $\mathrm{n} / \mathrm{a}$ & 19.7 \\
\hline Tucker pea + Pronghorn triticale & nd & $\mathrm{n} / \mathrm{a}$ & 115 & nd & $\mathrm{n} / \mathrm{a}$ & 29.2 \\
\hline 40-10 pea + Vivar barley & nd & 144 & 94 & nd & 33.6 & 22.0 \\
\hline 40-10 peas + Murphy oat & nd & 116 & 108 & nd & 27.6 & 23.6 \\
\hline 40-10 pea + Pronghorn triticale & nd & 146 & 116 & nd & 35.2 & 28.0 \\
\hline$L S D_{(0.05)}$ & nd & 12.0 & 20.78 & nd & 5.33 & 5.33 \\
\hline Significance & $n d$ & $* *$ & $* *$ & nd & $* *$ & $* *$ \\
\hline$C V, \%$ & nd & 4.0 & 8.3 & nd & 7.5 & 8.8 \\
\hline
\end{tabular}

Note. ${ }^{* *}$ indicates the treatments effect being significant at 0.01 probability. $\mathrm{n} / \mathrm{a}$ refers to not applicable, because the pea variety was not tested. nd refers to not determined. 


\section{Summary and Implications}

Plant height of cereals tended to be reduced in intercrops compared to respective monocrops, without any influence of the cereal type or pea variety. Only taller 40-10 pea tended to cause lodging of cereals in 2009 and 2011. Pea + cereal mixture in intercrops had higher moisture level in fresh forage than respective monocrops, apparently attributable to their pea portion. In 14 of the 18 treatments, there was less dry matter yield (DMY) from intercrops than respective monocrops. Shorter forage Tucker pea variety had less negative impact on DMY than taller 40-10 pea. Barley monocrop and intercrops had lower DMY than the respective oat and triticale systems.

Intercrops improved forage crude protein $(\mathrm{CP})$ content over the respective monocrops, which was enough to overcome the DMY penalty and produce more $\mathrm{CP}$ yield from intercrops compared to their monocrops. The $\mathrm{Ca}$ and $\mathrm{Mg}$ contents were improved by intercrops over the respective monocrops; they were greater with 40-10 pea than other pea varieties and with barley than oat or triticale. The P content also tended to be higher in intercrops than monocrops, without a consistent trend for cereal type or pea variety. The $\mathrm{K}$ and $\mathrm{S}$ contents were not consistently different between the cereal types and pea varieties or between the monocrops and intercrops. Forage from oat treatments had greater $\mathrm{Na}$ content than respective barley and triticale treatments. The $\mathrm{Cu}$ content was not different between the monocrops and intercrops, and tented to be greater for barley than oat or triticale treatments. Forage $\mathrm{Zn}$ content tended to be intercrops $>$ monocrops; and barley $>$ triticale $>$ oat treatments. Treatments had no influence on the Fe and Mn contents. The ADF and NDF fibre contents were similar for the intercrops and their monocrops, were greater for oat than barley or triticale treatments, and were reduced by drought. Some of the intercrops improved TDN content in forage, oat had less TDN than barley or triticale monocrops, and drought increased the TDN level. The forage $\mathrm{NE}_{\mathrm{L}}, \mathrm{NE}_{\mathrm{M}}, \mathrm{NE}_{\mathrm{G}}, \mathrm{RFV}$ and $\mathrm{NFC}$ showed similar trend as the TDN.

In addition to superior nutritive value, the pea + cereal intercrops provide diversity in cropping system, which can improve nutrient cycling, regulate local hydrological processes, reduce pest populations, and detoxify noxious chemicals (Altieri, 1995). The cereal + legume intercrops, where pea fix atmospheric $\mathrm{N}$ to meet their $\mathrm{N}$ requirements, have the added advantage of reducing $\mathrm{N}$ fertilizer input and may provide $\mathrm{N}$ and non- $\mathrm{N}$ benefits to subsequent crops. However, more work is needed to better understand the $\mathrm{N}$ and non- $\mathrm{N}$ benefits of incorporating cereal + legume forage intercrops into rotations with sole crops.

Vivar barley monocrop and its associated intercrops appeared to have lower forage DMY than other cereals monocrop and their intercrops. Vivar barley variety is a 6-row feed grain barley type and pronghorn triticale is considered an excellent alternative to feed barley or oats. Murphy oat is a forage type oat. Whether or not recently released forage type barley and oat varieties with forage type peas would out yield their monocrops needs to be investigated.

Overall, the trends for change by pea + cereal intercrops relative to their respective cereal monocrops showed decrease for few, improvement for several and no effect for several measured parameters (Table 15). There were some exceptions to the mentioned trend and the change was not always significant.

Table 15. Trends of change in measured parameters by pea + cereal intercrops relative to the respective cereal monocrops

\begin{tabular}{ll}
\hline Trend of Change by intercrops & Measured parameters \\
\hline Decrease & Cereal plant height, DMY, TDNY \\
Improve & $\mathrm{CP}, \mathrm{CPY}, \mathrm{DF}-\mathrm{CP}, \mathrm{Ca}, \mathrm{Mg}, \mathrm{P}, \mathrm{Zn}, \mathrm{TDN}$ \\
No effect & Soluble-CP, UIP-CP, K, S, Na, Fe, Mn, ADF, NDF, NE $, \mathrm{NE}_{\mathrm{M}} . \mathrm{NE}_{\mathrm{G}}, \mathrm{RFV}, \mathrm{NFC}$ \\
\hline
\end{tabular}

Results show that to optimize the hay, silage or green feed utilization for beef cattle, combinations of the desired yield and nutritional quality needs to be considered to achieve desirable objectives in specific situations. For example, monocrops may produce more DMY than pea + cereal intercrops while intercrops may provide forage with better nutritional profile. Similarly, oat and triticale systems may out yield barley systems, but barley systems may provide forage with better nutritional profile than oat.

As with any forage crop, there is a trade-off between yield and quality. Successful intercrops occur when each species occupies and accesses resources from different ecological niches while minimizing competitive interactions (Anil et al., 1998). For example, pea and barley may have different peak times for water and nutrient 
uptake or their leaf arrangements may allow for greater light utilization. In contrast, if a particular combination of species and or varieties occupy similar ecological niches, it is unlikely that forage intercrop yield advantages will be observed.

The tested intercrops did not increase DMY over the respective monocrops, but they indicated several nutritional quality benefits. For example, some or all of the intercrops tended to or improved $\mathrm{CP}, \mathrm{CPY}, \mathrm{Ca}, \mathrm{Mg}, \mathrm{P}, \mathrm{Zn}$, energy contents, RFV and NFC in forage. Thus, the improved nutritional quality indices made forage from intercrops more suitable for cows that need higher levels of these nutritional parameters. These improvements also present opportunities to substitute some grain or nutritional supplements in the beef cow diet with better quality forage by intercrops.

As no particular monocrop cereals or intercrops in the present study would be able to meet all the nutrient requirements of different categories of mature beef cows, some form of strategic supplementation would still be needed to meet their nutrition requirements.

\section{Acknowledgements}

The study was funded by Agricultural Opportunity Fund (AOF) of the Alberta Agriculture and Forestry (AAF), Alberta beef producers (ABP), and the municipalities of Big Lakes, Greenview, Smoky River and Northern Sunrise. The technical help by the other SARDA Ag Research staff is highly appreciated. Sincere thanks are due to the farmers for providing land for the trials, St. Albert co-operative (Falher) for donating fertilizers, A\&L Laboratory for discount on sample analyses, and Lilian Trudeau, Agriculture Financial Services Corporation of Alberta for providing the SSM data. Thank you to the editor and two anonymous reviewers, very valuable suggestions from them have substantially improved the manuscript.

\section{References}

AARD (Alberta Agriculture \& Rural Development). (2004). Cereal/Pea or Spring Cereal/Winter Cereal Intercropping - Frequently Asked Questions. Retrieved July 23, 2017, from http://www1.agric.gov.ab.ca/ \$department/deptdocs.nsf/all/faq8444

Aasen, A., Baron, V. S., Clayton, G. W., Dick, A. C., \& McCartney, D. H. (2004). Swath grazing potential of spring cereals, field pea and mixtures with other species. Can. J. Plant Sci., 84, 1051-1058. https://doi.org/ 10.4141/P03-143

Anil, L., Park, J., Phipps, R. H., \& Miller, F. A. (1998). Temperate intercropping of cereals for forage: A review of the potential for growth and utilization with particular reference to the UK. Grass Forage Sci., 53, 301-317. https://doi.org/10.1046/j.1365-2494.1998.00144.x

Brooker, R. W., Bennett, A. E., \& Cong, W. F. (2015). Improving intercropping: A synthesis of research in agronomy, plant physiology and ecology. New Phytologist, 206, 107-117. https://doi.org/10.1111/nph.13132

Carr, P. M., Martin, G. B., Caton, J. S., \& Poland, W. W. (1998). Forage and nitrogen yield of barley-pea and oat-pea intercrops. Agron. J., 90, 79-84. https://doi.org/10.2134/agronj1998.00021962009000010015x

Carr, P. M., Richard, D. H., \& Woodrow, W. P. (2004). Barley, Oat, and Cereal-Pea Mixtures as Dryland Forages in the Northern Great Plains. Agron. J., 96, 677-684. https://doi.org/10.2134/agronj2004.0677

Corre-Hellou, G., Corre-Hellou, J., \& Fustec, Y. (2006). Interspecific competition for soil N and its interactions with $\mathrm{N}_{2}$ fixation, leaf expansion and crop growth in pea-barley intercrops. Plant Soil, 282, 195-208. https://doi.org/10.1007/s11104-005-5777-4

Demarguilly, C., \& Weiss, P. (1970). Tableau de la valeur alimentaire des fourrages. Paris, INRA.

Dhima, K. V., Lithourgidis, A. S., Vasilakoglou, I. B., \& Dordas, C. A. (2007). Competition indices of common vetch and cereal intercrops in two seeding ratio. Field Crops Res., 100, 249-256. https://doi.org/10.1016/ j.fcr.2006.07.008

Gill, K. S., \& Omokanye, A. T. (2016). Spring Triticale Varieties Forage Yield, Nutrients Composition and Suitability for Beef Cattle Production. Journal of Agricultural Science, 8(10), 1-14. https://doi.org/10.5539/ jas.v8n10p1

Gill, K. S., Omokanye, A. T., Pettyjohn, J. P., \& Elsen, M. (2013a). Evaluation of forage type barley varieties for forage yield and nutritive value in the Peace Region of Alberta. J. Agric. Sci., 5, 24-36. https://doi.org/ $10.5539 /$ jas.v5n2p24 
Gill, K. S., Omokanye, A. T., Pettyjohn, J. P., \& Elsen, M. (2013b). Agronomic performance and beef cattle nutrition suitability of forage oat varieties grown in the Peace Region of Alberta, Canada. J. Agric. Sci., 5, 128-145. https://doi.org/10.5539/jas.v5n7p128

Igne, B., Gibson, L. R., Rippke, A., \& Hurburg, C. R. (2007). Triticale moisture and protein content prediction by near-infrared spectroscopy. Cereal Chem., 84, 328-330. https://doi.org/10.1094/CCHEM-84-4-0328

Izaurralde, R. C., Juma, N. G., \& McGill, W. B. (1990). Plant and nitrogen yield of barley-field pea intercrop in cryoboreal-subhumid central Alberta. Agron. J., 82, 295-301. https://doi.org/10.2134/agronj1990.00021962 $008200020024 x$

Javanmard, A., Nasab, A. D. M., Javanshir, A., Moghaddam, M., \& Janmohammadi, H. (2009). Forage yield and quality in intercropping of maize with different legumes as double-cropped. J. Food Agric. Environ., 7, 163-166.

Li, H, Zhang, F., Rengel, Z., \& Shen, J. (2014). Rhizosphere properties in monocropping and intercropping systems between faba bean (Vicia faba L.) and maize (Zea mays L.) grown in a calcareous soil. Crop and Pasture Science, 64, 976-984. https://doi.org/10.1071/CP13268

Lithourgidis, A. S., Dhima, K. V., Vasilakoglou, I. B., Dordas, C. A., \& Yiakoulaki, M. D. (2007). Sustainable production of barley and wheat by intercropping common vetch. Agron. Sustain. Dev., 27, 95-99. https://doi.org/10.1051/agro:2006033

Lithourgidis, A. S., Dordas, C. A, Damalas, C. A., \& Vlachostergios, D. N. (2011). Annual intercrops: an alternative pathway for sustainable agriculture. Aust. J. Crop Sci., 5(4), 396-410.

Lithourgidis, A. S., Vasilakoglou, I. B., Dhima, K. V., Dordas, C. A., \& Yiakoulaki, M. D. (2006). Forage yield and quality of common vetch mixtures with oat and triticale in two seeding ratios. Field Crops Res., 99, 106-113. https://doi.org/10.1016/j.fcr.2006.03.008

NRC (National Research Council). (2000). Nutrient Requirements of Beef Cattle (7th ed.). Washington, DC: The National Academies Press.

Omokanye, A. T. (2014). Annuals for forage production. 2014 Peace Region Forage Agronomy Update, Peace Region Forage Seed Association, British Columbia, Canada, held at Rycroft, Alberta, Canada, March 25, 2014.

Soil and Plant Analysis Council. (1999). Soil Analysis Handbook of Reference Methods. Soil and Plant Analysis Council, Inc, Athens, GA.

Soil Classification Working Group. (1998). The Canadian system of soil classification. Agriculture and Agri-Food Canada Publication, 1646 (Revised).

Strydhorst, S. M., King, J. R., Lopetinsky, K. J., \& Harker, K. N. (2008). Forage potential of intercropping barley with faba bean, lupin, or field pea. Agron. J., 100, 182-190. https://doi.org/10.2134/agrojn12007.0197

Xue Y., Xia H., Christie P., Zhang Z., Li, L., \& Tang C. (2016). Crop acquisition of phosphorus, iron and zinc from soil in cereal/legume intercropping systems: A critical review. Ann. Bot., 117, 363-377. https://doi.org/10.1093/aob/mcv182

Yurchuk, T., \& Okine, E. (2004). Agri-facts: Beef Ration Rules of Thumb (Agdex 420/52-4). Alberta Agriculture Food and Rural Development Publication. Retrieved July 23, 2017, from http://www1.agric.gov.ab.ca/ \$department/deptdocs.nsf/all/agdex9146/\$file/420_52-4

\section{Copyrights}

Copyright for this article is retained by the author(s), with first publication rights granted to the journal.

This is an open-access article distributed under the terms and conditions of the Creative Commons Attribution license (http://creativecommons.org/licenses/by/4.0/). 